Technical Progress Report for the Project

$\mathrm{DOE} / \mathrm{PC} / 88920--\mathrm{T} 7$

DE91 000919

\title{
ELECTROCHEMISTRY OF Thiobacillus ferrooxidans REACTIONS WITH PYRITE
}

Principal Investigator: Prof. B. Pesic

Co-principal Investigator: D.J. Oliver

Reporting Period: January 1990-May 1990

U.S. DOE Patent clearance is not required prior to publication of this document

DOE Project Grant No.: DE-FG22-88PC88920 


\section{2}

\section{STATEMENT AND OBJECTIVES}

The objective of this project is to provide the fundamental information on the mechrnisms of bacterial leaching of pyrite. The knowledge of how bacterial leaching of pyrite functions is essential for design and development of a technology for coal cleaning with bacteria. The features of major electrochemical techniques will be examined to find out if any of them can provide a diagnostic information on the mechanisms of reiated reactions.

\section{SCIENTIFIC AND TECHNICAL PROGRESS}

\subsection{GENERAL}

The research in this reporting period was focused on one key parameter, which was how to improve the chemical activity of bacteria. Conceptually, the bacierial leaching of pyrite is dependent on chemical activity and concentration of bacterium cells. The activity of the bacterium cells can be modulated by modulating the conditions of the environment where the cells reside. The environmental conditions imply the solution composition with respect to $\mathrm{pH}$, heavy metals concentration, composition and concentration of extracellular produrts, temperature, and composition and concentrations of nutrient salts. In the same time, 
by modulating the chemical activity of bacteria via the environmental conditions their multiplication and therefore their concentrations can be also modulated.

\subsection{EXPERIMENTAL WORK}

The experimental apparatus was the same as explained in the previous reports. It consisted of a four liter fermenter, electrodes, and computerized potentiostat-galvanostat.

The activity of bacteria was monitored during the growth stages (fermentation) by cyclic voltametry. After the fermentation was finished, the bacterium cells were removed from the solution by filtration and its activity tested by the rate of redox potential change, the method previously developed by the author.

\section{Activity of $T$. ferrooxidans with time}

There is no literature information on the activity of $\underline{T}$. ferrooxidans with time. However, this information is needed and is very important for many reasons. In the fermentation reactor design area, it would be important to know at which stage of fermentation the bacterium reached its maximum activity and concentration. In the bioleaching area, it would be important to know about the fate of bacterium with respect to its activity at the prolonged leaching times. 


\section{4}

For the above reasons it was decided to perform very lengthy and time consuming, but very important, experiments to study the activity of $\mathrm{T}$. ferrooxidans with time. This study was performed by running fermentation experiments for different time lengths, extracting all the celis (harvesting) produced during that time interval, and determining their activity by calculating the rate constant of ferrous iron oxidation (redox reaction). The experimental procedure is described below.

A four liter fermenter was prepared and all medium (described in the previous reports) and nutrient salts (100 grams of ferrous sulfate) were added. Then a stock of $\mathrm{T}$. ferrooxidans culture (250 ml) was transferred from the incubator into the fermenter. After exact number of days of fermentation, the fermentation part of experiment was ceased, the filtration performed to remove the precipitates and the filtrate solution transferred to membrane filtration to remove the cells. The cells were also washed from the iron salts on the same membrane filter. After washing, the cells were removed from the filter membrane into a container by maintaining a constant volume of the cells $(34 \mathrm{ml})$. The prepared batch of concentrated cells was used to determine their activity with respect to the rate of ferrous ion conversion to ferric. To check the activity, a $0.5 \mathrm{ml}$ of concentrated cells was added into a separate electrochemical cell to measure the rate of ferrous ion oxidation. From the redox rate data, which represented the activity of $T$. ferrooxidans at the particular number of fermentation days, 
the iron oxidation rate constant was calculated and plotted. The results are presented in Figure 1 .

The analysis of data presented in Figure 1 show three distinct ranges of activities, one range of increasing activity and two ranges of decreasing activities. In the first range $(2,4$, and 5 days) the activity of $T$. ferrooxidans was increasing with time. This was expected and it is directly related to the exponential stage of bacteria growth. At 5 days of growth (fermentation) the population density of bacteria reached maximum and therefore the activity of bacteria reached the maximum.

During fermentation for longer periods than 5 days, the activity of T. ferrooxidans showed two exponential ranges of decreasing activities, 5-12 days (second stage), and 12-24 days (third stage). The activity decrease in the 5-12 day time interval was not dramatic and one can safely assume that activity of T. ferrooxidans in this time interval is high enough for practical leaching purposes. The most dramatic activity decrease occurred in the 12-24 days range. At the final studied time, 24 days, the activity of bacteria was very low almost non-existent.

The decrease of bacteria activity can be related to the exhaustion of the nutrient, ferrous sulfate. Ferrous sulfate became mostly oxidized tu ferric sulfate during the growth stage (stage I). The lack of food therefore could be the primary reason for the first 
stage of decreasing activity. During the oxidation of ferrous to ferric ion, which is necessary for bacteria growth, jarosite is also formed as the reaction byproduct. The jarosite formation initiates on the surface of bacterium cells. With time, the cells become embedded into the jarosite product and the cells die. The lack of food and the formation of jarosite product are the main reasons for the fast decay of bacteria activity in the second decreasing stage.

\subsection{SUMMARY}

1. The activity of $\mathrm{T}$. ferrooxidans with duration of fermentation was examined. It was found that there were three distinct stages of fermentation. The activity of $\underline{T}$. feriooxidans increased in the first stage because of the growth of the cells (multiplication). The activity of $\underline{T}$. ferrooxidans decreased in the second and third stage of fermentation.

2. The optimum fermentation time was 5 days. This time interval was well defined, and the activity of $\mathrm{T}$. ferrooxidans rapidly decreased before and after this time interval.

3. Decreased activity of $\underline{T}$. ferrooxidans beyond five days of fermentation is directly related to the lack of food and jarosite 
precipitation, i.e. the cells die.

\subsection{FUTURE WORK}

The future work will be related to the use of some other electrochemical techniques to study the role of $\mathrm{T}$. ferrooxidans with pyrite.

Some of cie previously done cyclic voltametry experiments will be repeated in order to find what exactly happens on the pyrite surface between 1.5 and 2.0 days of fermentation (See the annual report, 1989). A separate SEM study in this time region will be also performed.

\section{DISCLAIMER}

This report was prepared as an account of work sponsored by an agency of the United States Government. Neither the United States Government nor any agency thereof, nor any of their employees, makes any warranty, express or implied, or assumes any legal liability or responsibility for the accuracy, completeness, or usefulness of any information, apparatus, product, or process disclosed, or represents that its use would not infringe privately owned rights. Reference herein to any specific commercial product, process, or service by trade name, trademark, manufacturer, or otherwise does not necessurily constitute or imply its endorsement, recommendation, or fayoring by the United States Governmert or any agency thereof. The views and opinions of authors expressed herein do not necessurily state or reflect those of the United States Government or any agency thereof. 


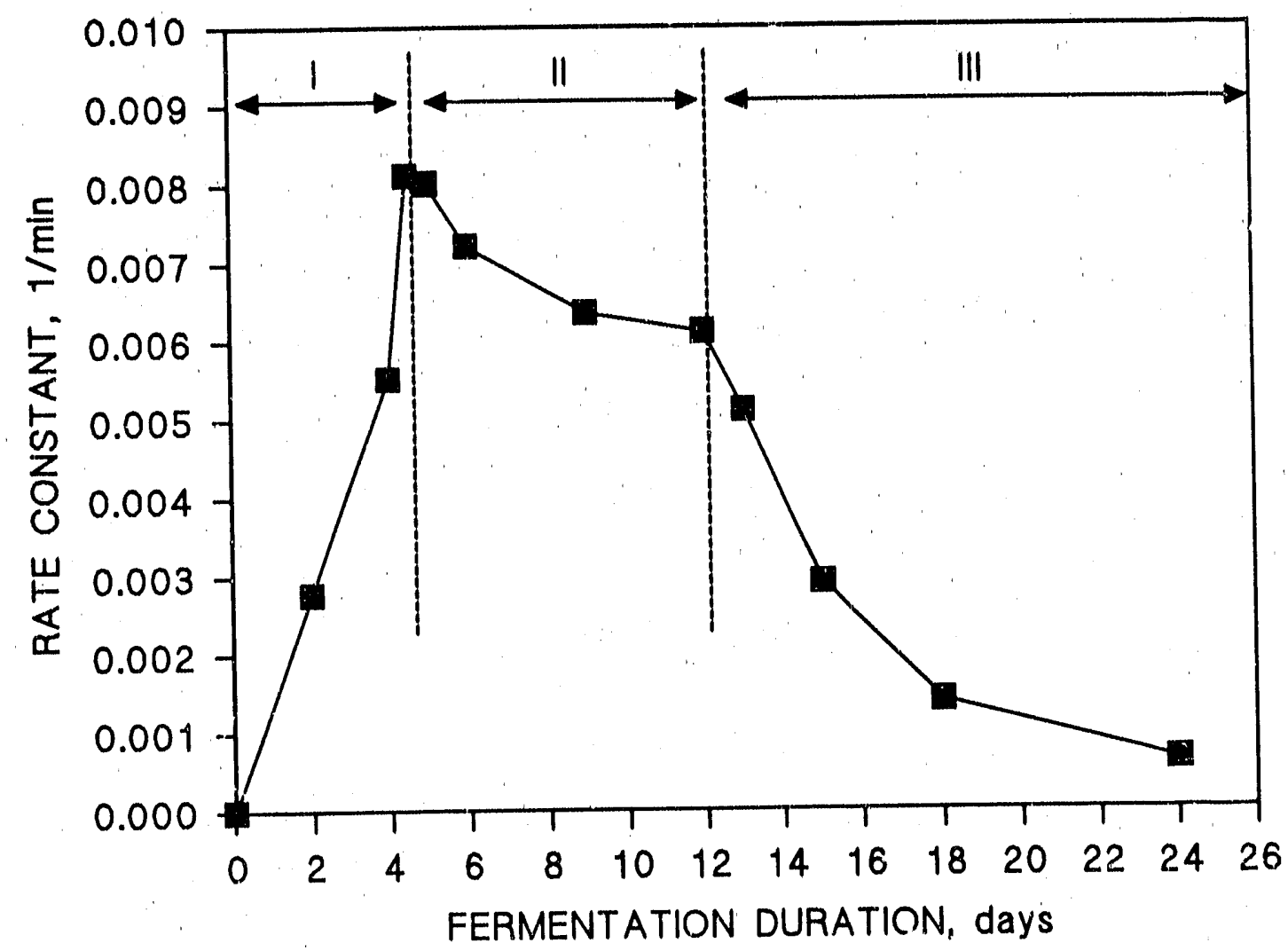

Fig. 1 Bacterla activity varlation with time. 

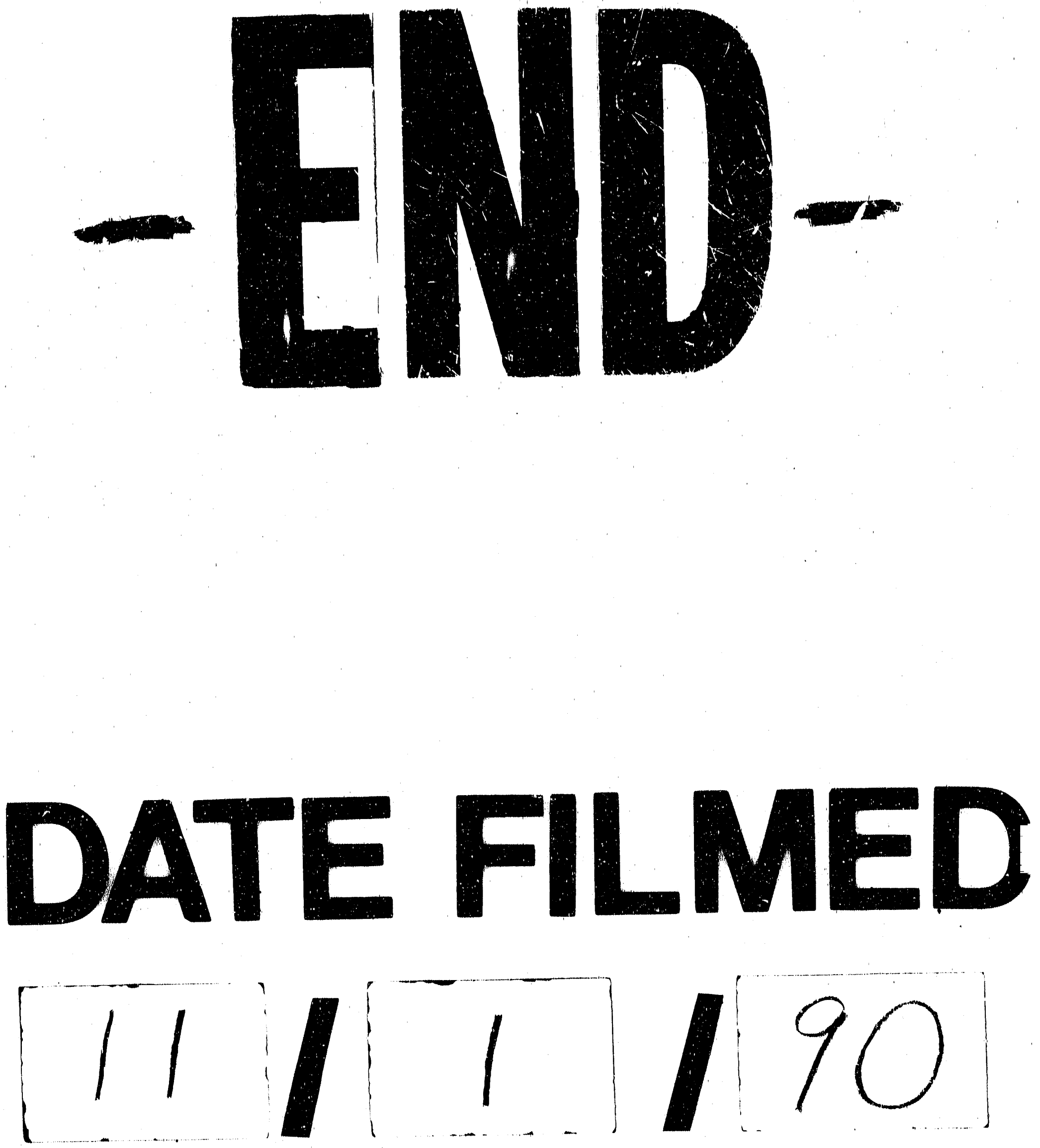
